\title{
Woman Subjection As Reflected In Sidhwa's Cracking India
}

\author{
Najia A. Zaidi \\ Department of English \\ University of Balochistan
}

\begin{abstract}
The Indian subcontinent gained independence from the British Raj in 1947, and got divided into two states: India and Pakistan. This division was the result of religious conflict that turned into a great tragedy of the region forcing millions to leave the part they were living in and killing large number of innocent people. Women became the worst victims of partition on both sides of the border. Sidhwa captures the position of woman through historical perspective. This paper examines the retelling of partition by Sidhwa in her novel Cracking India and portrays the exploitation, manipulation and oppression of women in relation to politics, religion and society. The publication of this novel establishes it as feminist text that calls for reconsideration of women's rights and status in Post-Colonial Pakistan.
\end{abstract}

\section{تلخيص المقال}

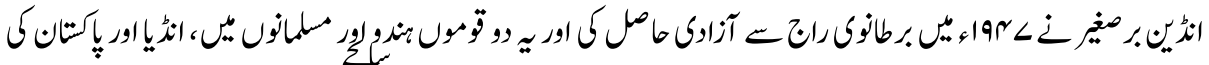

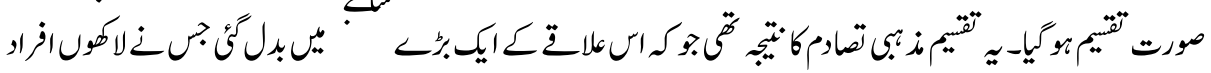

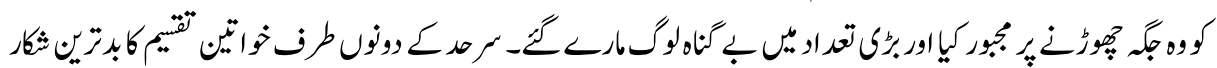

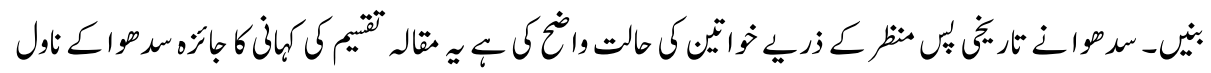

$$
\begin{aligned}
& \text { Cracking India }
\end{aligned}
$$

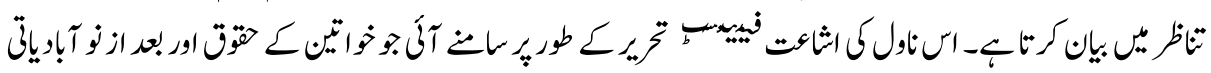

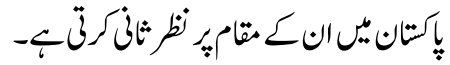

Literature on the momentous event of Partition and focusing on the circumstances of women tell shocking tales of systemic oppression. Bapsi Sidhwa, the pioneer of the English novel in Pakistan, examines pronounced gender bias against women in the region to which she belonged. Sidhwa in her novel Cracking India focuses on homelessness and displacement and other problems of women in relation to culture, religion and politics. Infact, the publication of Cracking India provided a much needed jolt to the writers of Pakistan and encouraged them to wield their pens in the cause of women. As this novel is a record of a particular history, the current paper would study woman subjection from historical perspective. Colonization and partition (the division of India into two states) deeply affected the lives of women in Indian Subcontinent. They were the worst victims of violence at the time of partition. The essay will make an endeavour to critically evaluate the relationship of culture, religion and politics in relation to women. 
Sidhwa in Cracking India shows that women were the worst victims of history and the system. Considered as property, restricted at home and barred from political participation, they succumbed to the siege laid by culture, political system and obscurantist junta. She captures the position and potential of women through historical perspective. Three of her novels are based on the themes emerging from the process of colonization and partition. Furthermore, Sidhwa gives immense importance to reality and truthful representation of facts. As Brittain (Brittain 1943:5) says, " Perhaps the means of salvation are already there, implicit in history, unadvertised carefully concealed by the war mongers, only awaiting rediscovery to be acknowledged with enthusiasm by all thinking men and women". In an interview Sidhwa answered to a question about the purpose of the novel in these words "To function as a recording of a particular history, hoping that one might learn lessons from that history, though I don't think one does. If we are not going to learn lessons, we are doomed to repeat our evils. Historically, people have gone on fighting each other for religion, for land, for women, for position, for greed - and those elements prevail still. Man's nature has not changed- but one can try, and hope it will". In another interview to David Montenegro (Dhawan \& Kapadia1996;15) she says: "At least, I think a lot of readers in Pakistan, specially with Ice Candy Man, feel that a I have given them a voice, which they did not have before. They have always been portraid in a very unfavorable light. It's been fashionable to kick Pakistan and its been done again and again by various writers living in the West ------ and I feel, if there is one little thing I could do, it is to make people realize; we are not worthless because we inhabit a poor country that as seen by western eyes as - primitive, fundamentalist country." Whereas, Cracking India is about the reawakening of memories with a purpose to examine facts with fresh outlook.

Sidhwa's approach to partition is multidimensional. She talks about politics, religion, society, hegemonic blocks and subaltern groups. It is in these subaltern groups that she tries to locate the space available to women and their status as perceived by culture, religion and politics. Leonard (Leonard 2007:11) in her article "Divided Homeland, Hostile Homes: Partition Women And Homelessness" writes that literature focusing on partition served two related goals. The first was to force a deeply ethically informed understanding of the condition of these women by viewing the predicament from within the subjectivity and offer empathy. Literature evoked the texture of the women's experience that was absent in the political appeals and subsequent debates. And second, whereas, the political discourse failed to, or did not want to imagine the horror that these women were suddenly confronted with it is this 'otherness' that the narrative evocatively apprehended. By the ironic undermining of the political debate, writers mediated a moral recognition of the women's pain. Partition literature focusing on a women situation accepts the fact that men cannot speak for women and therefore gives opportunity to the women to speak for themselves.

Partition not only brings the horrifying images of oppression and destruction but also 
vulnerability of women on both sides of the border. The deranging repercussions of partition claimed women in cruel and hideous manner. The story of partition mainly written by writers, directly and brutally affected women. Since South Asian Societies are patrolineal in nature, woman's humanity is not their concern. Sidhwas' observation of 1947 events clearly depicts women victimization as a result of "ethnic cleansing" an ideology involving all ethnic groups and obscurantists. However, it is important to note that colonization did not do much to bring reforms in woman development sector. Colonization Fariha (Fariha 1991:5) observes, did not necessarily improve the participation and position of women in Society". The encyclopedia of women in South Asia (2004:60) highlights the two concepts related to Pakistan but they serve as a base to all South Asian cultures and Society. First that woman are subordinate to men, and that all men's honor resides in the action of the women of his family". Cracking India reflects this mindset. The people belonging to different religions shared certain values specially related to movement and space allotted to women. As in the case of Lenny who is a Parsei suffering with polio which further marginalizes her position. Her parent's concern for her education is discouraged in these words: She'll marry- have childrenlead a carefree, happy life. No need to strain with study and exams" (Sidhwa, 1988:15).

The advantages of having a narrator who is polio-riddled, eight years old parsi girl Lenny are manifold; first, as a girl, she is marginalized; and second, her lameness further restricts her movements and make her dependent on others. Infact, in this case her lameness serves as an eye-opener. Finally, as a girl child she observes all events with strict neutral position which adds authenticity to the historical tale of Sidhwa. As Bharucha comments, "Lenny experiences enclosures within enclosures as her space shrinks. Her lameness is allied to her femaleness to deprive her of proper education".(2000:96)

Another striking example of discrimination against women and girls is the way "Papoo"is treated by her parents, specially by her mother. She lives in the servant quarter of Lenny and is about eleven years old, belonging to a lower caste. Despite sharing a good amount of work load, she is still brutally beaten and mistreated by her mother. As Lenny complains: "Papoo hardly even plays with me now. She is forever slapping the dough into chap patties, or washing, or collecting dung from the road and plastering it on the walls of their quarters". (Sidhwa,1988:94) Later her marriage to a man who is almost of her father's age reflects low value set on women's' lives. As Menon (2004:117 ) says:

"Socialization for gender differentiation and sex inequality starts early in a girl's life. Most of the things we associate with being male or female are cultural - they are socially determined. From birth to death a person is supposed to be inextricably and forever male or female. The whole range of social apparatus - names, clothes, toys, beliefs, behaviors and values are nothing but a complex process of labeling which begins when a child is born." 
In fact, the aim of the gendered and caste-based social and political structure was to keep the power in few hands and to oppress women and lower classes to ensure persistence of socio-political status-quo. Sidhwa has reflected this reality through "papoo". Kishwar Naheed (Kishwar Naheed 2004:181-182), a well-known Pakistani poet and feminist, depicts this picture in verse which is worth-quoting,

Use me!

Like a washed cloth

Squeezed, drip dry,

Chew me!

Like a Sweet

Dissolved to its core,

Grill me!

Every bit of my flesh

Tormented

Bids farewell

To each breath of life

Pulverize me!

I, like a dry bread

Will soften and crumble.

In Cracking India these barbaric trends are charted sometimes clearly and sometimes through satiric mode. Sidhwa's artistic skills are more appreciated the way she preserves her neutral tone. Her close observation of all faiths and the cultural practices make her a trustworthy observer of history. For instance, with reference to Muslim girls, she says: They must have heard their mothers and aunt say: Hasi to Phasi! Laugh (and) get laid------- but they know that smiling before man can lead to disgrace." (Sidhwa, 1988: 55)

Cracking India discusses the pervasive violence against women. They were killed, tortured and raped on both sides of the border in retaliation. Portraying the women situation on the eve of partition and migration, sidhwa writes in the Ice Candy Man:

"A train from Gurdaspur has just come in. Everyone in it is dead. They are all Muslims. There are no young women among the dead! Only two gummy- bags full of women's breasts" (Sidhwa,1988:149). Menon an Bhasin (1998:42-43) in their book on partiton Borders and Boundaries relate the account of a civil surgeon of Sheikhupura who testified to the fact finding team that "Among the chief types of injury inflicted on the wounded; he sites amputation of breasts of women and adds that six such cases of chopped - off breasts were brought to the refugee camp and all of them proved fatal. Very large number of women were forced into death to avoid sexual violence against them to preserve chastity and protect individual, family and community 'honor'. The range of sexual violation explicit in the above accounts - stripping, parading naked, 
mutilating and disfiguring ------ is shocking not only for its savagery, but what it tell us about women as objects is male constructions on their own honor. Women's sexuality symbolizes 'manhood' and its desecration is a matter of such shame and dishonor that it has to be avenged. Yet, with the cruel logic of all such violence it is women ultimately who are most violently dealt with as a consequence.

Sidhwa asserts that violence against women has many forms like child marriage, depriving girl child of education, verbal rebuke, rape and rejecting a woman who has been dishonored by men. Ironically, women also suffer violence at the hands of their male family members. One such case mentioned is that of Hamida, (Lenny's new Ayah). Hamida tells Lenny that she is a fallen woman. Unable to grasp the meaning, Lenny inquires from her godmother, who discloses: "Hamida was kidnapped by the Sikhs. She was taken away to Amritsar. Once that happens, sometimes, her husband- or familywon't take her back." (Sidhwa, 1988:215)

Hindu, Muslim and Sikh families refused to integrate raped and abducted women back into their families. Unfortunately, many women committed suicide before and after abduction. In September (1947:11) Gahdhi said:

"I have heard that many women who did not want to lose their honour chose to die. Many men killed their own wives. I think that is really great, because I know such things make India brave. After all, life and death is a transitory game---- the women have gone with courage-----They were not just a handful, but quite a few. When I hear all these things I dance with joy that there are such brave women in India". (CWMG, vol.98:202).

Not only was their former homeland partitioned and transformed into a foreign country, but their homes and most intimate relationships were also demolished with the loss of chastity. Women in South Asia have suffered ethnocidal rape at the time of partition, during the Bangladesh war, in Kashmir and in the interminable series of communal riots that have marked the subcontinent's modern historical experience (Leonard, 2007:23). Kamla and Bhasin (Kamla and Bhasin 1998:43), while discussing the issue of marking the body observed "The most predictable form of violence experienced by women, as women, is when the women of one community are sexually assaulted by the man of the other, in an overt assertion of the their identity and a simultaneous humiliation of the other by 'dishonoring' their women. In this respect, Chaudhri (Chaudhri, 1964:41) says, "the rape and molestation of Hindu, Sikh and Muslim women before and after partition probably followed the familiar pattern of sexual violence and of attack, retaliation and reprisal". All the communities strictly believed that whenever a woman belonging to a certain community was raped by a man from another community that "particular Woman" was considered unchaste, unclean and untouchable. The belief was "the mind is second to the body, if the body is tainted". Thus the woman's body becomes the site of victory and vengeance, and humiliation. 
The body of the woman was greatly politicized during partition. Leonard (2007:23) explains more clearly these motives: "Anti-colonial nationalisms in South established a direct correlation between women's purity and it's vulnerable nation. Chaste woman's body $=$ Uncolonized national space, and treated woman's body as symbolic territory. However, , while this may be a common feature of anti-colonial nationalisms, the marked refusal within Hindu and Sikh communities to recognize the metaphorical nature of chastity and it's lateralization, both in acts of rape and the repudiation of abducted women is distinctive. According to this logic, the woman's body, sexually abused by the rival community in the partition, becomes a representative of the fallen nation.

Leney's Ayah (Shanta) enjoys unique position in sidhwa's novel. Chandra (1996:178) views Ayah as a strong and self-willed person and her presence also exerts powerful influence on Lenny. In the article "Ice Candy Man; a Feminist Perspective", the Ayah is described there "The Ayah is a flame of sensuousness and female vitality around home the male moths hover constantly and hanker for the sexual warmth she radiates. She acts like the queen who controls the actions and emotions of her male admirers: the Fallatis hotel cook, the government house Gardner, the Boucher, the compactly muscled "head and body" Masseur and Ice Candy Man. The measure of Ayah's power is seen when she objects to the political discussion among her multi religious admirers, as she fears discord. The Ice Candy man defers to her wish and says, "Its just a discussion among friends ------- such talks help clear the air ------ but for your sake, we wont bring it up again. Epitomizing the strength of the femininity of a female, sidhwa infuses in Lenny the idea of independence and choice. Unfortunately Lenny's beloved Ayah is kidnapped and raped by the Ice Candy Man and his friends." Sidhwa graphically shows the Ice Candy Man's betrayal of Ayah in these words,

"The man drag her in grotesque strides to the cart and their harsh hands supporting her with careless intimacy, ---- their lips stretched in triumphant grimaces." (Sidhwa,!988:183)

However, after her abduction she suffers a lot. She is raped by "drunks, peddlars, sahibs and cut throat" She is kept at Kohta and lives as Ice Candy Man's mistress, who later marries Ayah and changes her name from Shanta to Mumtaz. Lenny's godmother rescues her from the trap of Ice Candy Man. Ayah avails the opportunity to leave Pakistan with godmother's help saying, "I will not live with him (Ice Candy Man)"

Woman's body is shown not only as a symbol of colonization but also a form of revenge one community takes from another. As Kate Millet (Kate Millet 1969:97) has put it, "Rape is an offence, one male commits upon another - a matter of abusing his women."

To some extent, the respective states of India and Pakistan made efforts to rehabilitate abducted women. However, they did this by uprooting their new homes where they had 
settled and became part of the family. In some cases, the abducted woman's relatives got them married to their abductors, but the state agents remained indifferent to the pleas of women during the recovery mission. Therefore, Leonard (Leonard 2007:12-13) regrets, " Neither position - the politically and the liberal - consulted the will of the women in question, whom they had uprooted.

Sidhwa in powerful, memorable and thought provoking words compressed the brutal reality as such: "Victory is celebrated on a woman's body, vengeance is taken on a woman's body"( 1988:190)

Menon in her book Female Exploitation and Women's Emancipation says, "it has been distressing experience all over the world that in any conflict war, civil strife, communal riots or disturbances women and children become the unfortunate victims of violence and atrocities. Women are not only widowed but also become victims of rape." (2004:116) Sidhwa in her dialectic of the process of colonization and partition shows how displacement and dislocation of women lead to "disoriented subjectivity". Hence, the rape of Ayah by Ice Candy Man and compatriots reveals maximum violence, possession and suppression of her identity as a free woman practicing her faith. Similarly, the way Hamida is maltreated and disowned by her family members due to being dishonored by the Sikhs indicates the presence of same cultural values in relation to women despite having different faiths. Another important fact emerging from close reading reveals the absence of "English Women" at decision making levels. Therefore, women belonging to different faiths in undivided India were restricted politically and culturally. As Zafar (1991:8) says that "Education was clearly seen as means for loosening the control exercised by men over women, and it is precisely for this reason that it played such a central role in the struggle for women's rights in India".

However, as mentioned earlier that all the communities living in the Indian subcontinent adopted values echoing more or less similar sentiments. According to a report on Women's Education in India (1991:4), "Girls are too useful in the house and parents think that they forget and dispose ordinary household duties if they learn how to read and write. Religion is also considered as one of the constraints fracturing the existence of women maintaining status quo to serve the vested interests of politicians and obscurantists. As Sidhwa's penetrating insight unveils this hideous religion-political doctrine in these words:

"One day everybody is themselves- and the next day they are Hindus, Muslims, Sikhs, Christians. People shrink, dwindling into symbols. The Ayah is no longer just my all encompassing- Ayah- she is also a token- a Hindu." (1988: 93 )

The brutal clash between different communities depicted in the novel is owing to the disharmony created by religious leaders. Maghissi in Bennett's (2005:86) Muslims and 
Modernity clearly says what Sidhwa asserts in the text. He says that "Colonial misdemeanors do not excuse the clerics who painstakingly protected women for many centuries against ideas, institutions and relations". Shamsie also comments that Sidhwa "skillfully shows how Sikh/Hindu-Muslim tensions arose and religious differences crept into people's lives----and brutalized South Asian society" (1997:xxx). Lenny observes prejudice against women as she grows older: "Our shadow glides over a Brahmin pundit...... Our shadow has violated his virtue. The Pundit cringes.....He licks at his food as it is infected with maggots. Squeamishly picking up the leaf, he tips its contents behind a bush and throws away the leaf..... I am a diseased maggot. I look at Yousaf. His face is drained of joy, bleak, furious. I know he too feels composed of shit, crawling with maggots.

Now I know surely. One man's religion is another man's poison. I experience this feeling of utter degradation, of being an untouchable excrescence, an outcast again, years later when I hold out my hand to a Parsee priest at a wedding and he, thinking I am menstruating beneath my facade of diamonds and sequined sari, cringes." (Sidhwa,1988:)

Since partition is the shaping force in Cracking India, violence and atrocities committed by one community against the other, by the powerful against the weak, by men against women shows fragmentation of society as a whole and its effects on the little mind of Lenny is depicted as such:

"I pick out a big, bloated celluloid doll. I turn it upside down and pull its legs apart-------Adi and I pull the dolls' legs, stretching it in a fierce tug- of -war, until making a wrenching sound it suddenly splits---- I examine the doll's spilled insides and, holding them in my hands collapse on the bed sobbing."(Sidhwa,1988:138)

Kapadia (Kapadia 1996:41) in his article "Communal Frenzy And Partition" compares Sidhwa with Atia Hussian. He writes "another partition novel Atia Hussain's sunlight on a broken column 1961 also uses a narrator heroine to similar effect ------ Laila reveals the Trauma of partition through her memories and insights offer Taluqdar family disintegrating. Like in the Ice Candy Man, the enigma of partition is sensitively shown, when Zahra, her cousin married in Pakistan, returns to Hassanpur. She quarrels with Laila about protection of Muslim culture and language. The disagreements were no longer youthful verbal quarrels but echoed bigger divisions. Laila surmises the most cruel concept of partition when she says, "In the end, inevitably we quarreled, and though we made up before we parted, I realized that the ties which had kept families together for centuries had been loosened beyond repair". Sunlight on a Broken Column details the disintegration of a family due to partition which cost internal ruptures and ethnic anxieties and the Zenana (The world of women from different angles). Hossain's heroine, like herself, is well educated and has the courage to defy and deviate from the norm. Barucha (Barucha 2001:106) comments that by admitting that she loves Ameer, 
Laila breaks the code of the Zenana where even husbands and wife's cannot live with one another and where love between men and women was associated with sex, and sex was sin. Laila is outraged by this and rejects the Zenana world and the politics of patriarchy to create her own space (P-106). Leaving Laila aside, all other remaining female characters remain dutiful to family values and customs and sometimes in the words of Nasta (2003) ---- "caught within the conflicting demands of class gender and partition".

Violence against women restricted their political activities. Low literacy also limited women participation in the political process. Whenever, women raised their voices, challenging male authority and trying to become a part of political machinery, they invited the wrath and anger of male relatives, religious leaders and community intellectuals. Though some parts of the subcontinent were more accommodating to women's needs and rights, but throughout the region there were clear signals of women submission to patriarchal doctrine and promoting the typical role model as wife and mother. Gandhi Ji with the vision of the reformer and thorough understanding of the art of the politics played an instrumental role in allocating public space to women. He encouraged active women participation in freedom movement against Imperial forces but never wanted women to compete for power. Considering women as an embodiment of sacrifice, he wanted them to purify politics through practically demonstrating the virtues of self-less devotion, patience and suffering thereby preserving the structure of patriarchal society. Gandhi Ji's visit to Lahore is given special treatment by Sidhwa in these words: "Ganghijee is certainly ahead of his time. He already knows the advantages of dieting. He has steered his way into the news and made headlines all over the world." (1988:86)

Refering to Gandhi Ji's views about women, Barucha observes, "Unlike the hyper masculine colonizing male, Gandhi deliberately cultivated the feminine side of his personality to advocate "female passivity" as opposed to male aggressiveness but his womanliness was that of a de-sexed mother rather than that of a woman as wife. Gandhi's unilateral vow of celibacy within marriage and his subsequent experiment in curbing his sexuality are too well-known to recount here. However, what needs to be noted is the enclosure of women in the mould of the mother. Through, his straitjacketing, men have sought to control, domesticate and neutralize female power." Sidhwa through Lenny assesses Gandhi in these words,

"Some years later- when I realized the full scope and dimension of the massacres- that I comprehended the concealed nature of the ice lurking deep beneath the hypnotic and dynamic femininity of Gandhi's non-violent exterior. And then, when I raised my head again, the men lowered their eyes." (1988:88).

Sidhwa weaves the entire fabric of a multiple history of social, cultural and political relationships combined with different voices and systems of belief. Another aspect 
suffering in the novel is the link between class and oppression. Generally, women from lower class become the victim of aggression and suppression as in the case of "Papoo" and "Hamida". Furthermore, colonization had created a culture that was "bourgeois friendly" which Chakrabarty calls "trichotomous ideational division on which modern political structures rest e.g. the state, civil society and the (bourgeois) family" (1992:11). Colonization therefore, strengthened male domination through educating women in the name of modernity, but still keeping them under the subject hood of patriarchal order. As Lenny's mother, aunt and godmother belonged to a community that was well-educated but cultural traditions and norms reigned supreme. Though, Lenny's mother and godmother attended meetings discussing political situation, but they remained silent spectators and were not a part of decision making process.

\section{Conclusion}

Sidhwa, as a feminist, works within a framework that conforms to certain traditional and progressive elements. She navigates a path through a bewildering maze of systems and beliefs, portraying a typical sense of dislocation experienced by women. The position of women in relation to culture, religion and politics is the focal point. Consequently, this relationship exposed the "silent mechanism" that permeated all the agencies of change and reform. Since the agenda of colonization was "complete subjection to imperial rules and regulations", the British Raj empowered certain vocal agencies like feudal, religious leaders and the bourgeois to institutionalize their ideology, serve their objectives and extend their agenda. . The result of this interlocked connection was "thought control" which led to the marginalized position of lower classes and women. As the dictum of colonization operated on "voicelessness, powerlessness and submissiveness" women were more likely to be the victim of this "less ness politics".

The strategy of colonial politics was to make women a part of their struggle where the rallying causes were either nationalism or the slogan of separate homeland. Sidhwa believes that until and unless women are taken out of the darkness of ignorance and educated about their rights, not much can be done to change the system. Sidhwa herself being the product of South Asian culture thoroughly understands the engrossing conflict of the third world women. To sum up Ice-Candy Man clearly throws light on the prejudices against women within the various religious groups as well as Pakistani society in general. The text produces an image of average third world woman, who is uneducated, tradition bound, victimized and has no control over her body and sexuality. Men on the other hand are providers, protectors, and decision makers at all levels. Another theme emerging from the text is gender and class. Sidhwa asserts that bourgeois woman lead a privileged life and their identity places them in a better political and economic position. However, on the other hand, the working class women become the victim of oppression. Lenny's Ayah is the best example of victimization on the basis of sex and class. The text portrays Ayah as a bold woman who does not compromise her 
right of self worth. Lenny's godmother is also an embodiment of innate goodness, wisdom, authority and amazing humor. Through her narrator Lenny, Sidhwa gives voice to the marginalized groups in India and Pakistan. Finally, Ice-candy Man is a Pakistani version of partition and an important addition to the list of partition novel. Chandra calls "Ice Candy man a feminist text in the true sense of the term, successfully attempting to bring to the centre stage the female protagonists. These protagonists while on the one hand, become alive on account of their realistic presentation, on the other, they serve as means of consciousness - raising among the female segments of society" (Sidhwa 1996:182).

\section{References}

Brittain, vera. (1943). Testament of Youth, London: Gollancz

Bharucha, Nilufer. (2001). "Inhabiting Enclosures and Creating Spaces: The World of Women in Indian and Pakistani Literaure in English "Post Independence Voices in South Asian Writings, edited by Alamgir Hashmi, Malashki lals, Victor Ramraj. Islamabad: Alhamra.

Bennett, Clinton. (2005). Muslims and Modernity, New York: Continuum

Carter, Ronald and MacRae, John. (2001). The Routledge History of English Literature in English. London: Routledge.

Chakrabarty, Dispesh. (1992) "Postcoloniality and the Artifice of History: Who speaks for Indian Pasts?" Representations Winter 11

Chandra, Subhash (1996). Ice Candy Man: A Feminist Perspective. The Novel of Bapsi Sidhwa. New Delhi: Prestige Book

Dhawan, K H. and Kapadia Novy. (1996). The Fiction of Bapsi Sidhwa. Prestige Books, Delhi, India

Kapadia, Novy. (1996). Comperative Perspective: The Novel of Bapsi Sidhwa. Prestige Books, New Delhi, India

Leonard, Debali Mookerjea. (2007). Divided Homelands, Hostile Homes: Partition, Women and Homelessness. Interpreting Homes in South Asain cultures. ed by Malashri Lal and Sukrita Paul Kumar, Dorling Kinderley, Dehli, India

Menon. Latika. (2004) Female Exploitation and Women's Emancipation. Kanishka Publishers, New Delhi, India

Menon, Ritu and Bhasin, Kamla. (1998) Boders and Boundaries. India Kali for Women 
Millett, Kate. (1969) Sexual Politics. Doubleday, New York

Nasta, Susheila. Home Truths. (2003) Fictions of the South Asian Diaspora in Britain. Palgrave, New York

Sangh, Mitra and Kumar, Bachchan. (2004) Encyclopaedia of Women in South Asia. kalpaz Publications, India

Sidhwa, Bapsi. (1988) Ice- Candy Man . Penguin, New Delhi, India

Shamsie, Mueeza. (1997) A Dragonfly in the sun. Oxford University Press, Karachi, Pakistan

Spivak, Gayatri ChakravortyI. (1988) Marxism and Interpretation of Culture, ed. Cary Nelson and Lawrence Grossbeg. Urbana: University of Ilinois Press

Zafar, Fariha. (1991) Finding Our Way, ASR Publications, Lahore, Pakistan

Najia Asrar Zaidi is Assistant Professor in the Department of English, University of Balochistan. 